\title{
Professional Training of Pedagogical Disciplines Teachers in the Master's Education
}

\author{
Nadiya Shcherbakova, Kateryna Shcherbakova
}

The article deals with the actual theoretical and methodical problem of improving the professional training quality of pedagogical disciplines by future teacher in the conditions of the master's studies.

The attention is focused on the creation and implementation in the educational process of the of higher education institution the organizational and pedagogical conditions that ensure the formation of teacher's readiness for professional activity.

The purpose of the article is to substantiate the theoretical and methodological foundations of future teacher preparation on the basis of an andragogical model. The model is based on the organization of the future teachers' independent work through the use of different theories and innovative technologies.

Structural and functional model includes such elements as: aim, motivation, educational process organization, ways to activate students' independent activity and its result as the readiness of higher education students to teach pedagogical disciplines in higher education institutions.

The investigated work allows us to argue that the organization of the educational process on the basis of personal, contextual, theoretical, methodological and activity approaches with the use of undergraduate educational projects in the independent work provided the experimental methodology with sufficient efficiency.

Keywords: future teacher preparation, andragogy, educational projects, personal, contextual, theoretical and methodical, activity approaches.

\section{Introduction}

Scientific research of national and foreign scientists and teaching experience of the article authors proves that improving the quality of professional training of specialists depends, first of all, on the organization of the educational process in higher education and the motivation of higher education students to solve educational problems put forward by the society. 
In the legislative and regulatory acts on higher education (the Law of Ukraine «On Higher Education», the National Framework of Qualifications, the Concept of organizing the preparation of masters in Ukraine, etc.) state policy of Ukraine is aimed at the development of two-stage professional training (bachelor's and master's degree), to increase the prestige and social status of the teacher, providing the conditions for the professional and cultural growth.

The building system process of professional training in the magistracy is carried out due to its peculiarities, namely: goals and objectives of education, the level of the higher education applicants motivation for pedagogical activity, initial professional experience and readiness of future specialists who have already had a bachelor's degree (Artemova, 2015; Gromkova, 2012; Kremin, 2005; Oliynyk, 2015; Vitvitska, 2003 etc.).

The analysis of scientific research and pedagogical practice shows that one of the driving forces of the future teacher's professional training is, first of all, an increase in his / her competence and creative potential. This is achieved by quickly modifying the content of the educational material and mastering it on a subject-subject basis. The organization of different forms and types of training in higher education is based on competent, active, theoretical, methodological and contextual approaches (Aristova, 2008; Artemova, 2015; Verbytskyi, 2009). At the same time, modern national scientists (Belenka, 2018; Zharovtseva, 2006; Oliynyk, 2015 et al.) consider professional training as a purposeful process of direct mastering by a future specialist of a theoretical and practical base of a certain profession.

We consider the teacher's professionalism of the higher educational institution as the most powerful factor of socio-cultural, spiritual, intellectual development of pedagogical intelligentsia, who is intended to provide the preparation of higher education applicants for practical pedagogical activity.

The outcome of this process is: the teachers' readiness as activity subjects to perform professional tasks in different conditions and at different levels of production organization, its competence in the content, organization and methods of implementation of this process.

In modern pedagogical literature, the term «professional training» is equated with the term «professional education». Thus, S. Goncharenko characterizes the professional education as training specialists of different qualification levels for employment in one of the branches of national economy, science, culture; as an integral part of a unified system of public education, and the content of vocational education includes an in-depth review with the scientific foundations and technologies of the chosen type of work, the inoculation of special practical skills and abilities of the 
formation of psychological and moral qualities of the person, important for work in a certain sphere of human activity (Goncharenko, 1997).

In M. Oliynyk's studies, the professional preparation of the future specialist in preschool education is considered as a process aimed at the formation of a system of basic professional competences, among which the author identifies key (social, communicative, general cultural, cognitive), general and multicultural (linguistic, speech, ecological) and competencies that are a prerequisite for the modern educator formation (Oliynyk, 2015).

One of the professional training areas of specialists in pedagogical activity, in particular to teaching special disciplines in higher education institutions, is the focus on the integration of the content of education, which allows the systematic presentation of information in new organic relationships, which affects the knowledge quality, students' skills and pedagogical experience (Belenka, 2018).

Subject integrity, according to scientists (Belenka, 2018) provides an opportunity to establish order and unity, thoughtfulness, coordination between the elements of knowledge. The above-mentioned research by scientists is certainly a significant contribution to solving many aspects of our problem. However, they do not pay much attention to the peculiarities of teacher training in higher pedagogical education, including preschool and elementary.

A comparative analysis of pedagogical science data and the results of mass pedagogical practice show some contradictions in the organization of the specialists' educational activities that is: the effectiveness of innovative educational concepts has been proved in theory, but mass pedagogical practice is very slowly trying to turn them into real activities. On the other hand, the progressive pedagogical experience of innovative pedagogues is not always theoretically justified to the level of pedagogical technology that gives a stable positive, predicted educational result. The way to overcome these contradictions depends on the quality of professional training of future teachers of pedagogical disciplines, in particular preschool and elementary direction even during their study in higher education institutions.

The obtained results of work with the students of the magistracy allow presenting their own experience in the preparation of the pedagogical disciplines future teachers on the andragogical model of teaching.

The purpose of the experience organization: theoretically substantiate and experimentally test the impact of created organizational and pedagogical conditions on the level of professional readiness of future specialists to teaching. 


\section{The task of accumulating experience:}

- to characterize the state and development prospects of the problem of teacher training in pedagogical disciplines;

- to define and theoretically substantiate organizational and pedagogical conditions for ensuring the professional training of future teachers of higher education institutions for professional activity;

- to analyze directions for content design and implementation of innovative technologies according to the andragogical model of the specialists' professional training.

\section{Methods of experimentally experienced search:}

- general scientific is analysis, synthesis, systematization of scientific information, which presents the problem of the professional training; problem-targeted analysis of legislative and regulatory documents, scientific and scientific and methodological studies on the problem;

- comparative and meaningful is the prognosis and interpretation of the analysis results to study the experience of organizing preofessional training of higher education applicants in the magistracy according to the andragogical model;

- empirical and diagnostic is questioning, testing, pedagogical observation, interviewing, innovative technologies introduction in the process of education by the second-level higher education students, the obtained data analysis, their quantitative processing.

\section{The theoretical part of the work}

The source of the study is based on the content of state and regulatory documents in the field of education, in particular the requirements for the quality of the future specialists training in teaching pedagogical disciplines in higher education institutions, scientific works of national and foreign scientists (monographs, dissertations, articles), materials of scientific conferences devoted to the actual problems of higher education, the study of progressive pedagogical experience.

A retrospective analysis of the formation and development of higher education training systems in the field of pre-school and primary education shows that in the early twentieth century, when public preschool education was actively involved in society, the activities of Froebel courses in Kyiv and Kharkiv occupied an important place in Ukraine. These courses worked as pedagogical institutes. Their activity can be considered as the beginning of formation of the national system training of highly qualified specialists. The training of specialists was carried out in two stages: the first stage (2 years) 
covered the preparation of kindergarten teachers; the second (1.5 years) provided the pre-school instructors, kindergarten organizers and teachers of various levels pedagogical institutions. Significant theoretical and practical contribution to the development of the training specialists program of that time made S. Rusova, N. Lubinets, T. Lubinets, etc.

In the context of determining the content, forms and methods of training future teachers were most effective in the 50-80s of the XX century. Significant at this stage of development of the higher school were the studies of O. Abdulina, F. Honobolin, I. Ziazyun, N. Kuzmina, O. Moroz, V. Slastyonin, A. Shcherbakov and others.

In the 1990s, domestic higher education institutions gained considerable independence. Professional training of specialists at the appropriate levels was carried out and still is fulfilled by higher education institutions (universities, academies, institutes and colleges). Educational institutions have the right to award higher education applicants i.e. future teachers, an educational degree, including a master's degree. This degree is awarded as a result of the successful completion of their educational and scientific and master's program.

Describing the content of professional training, scientists emphasize that it is a system of organizational and pedagogical measures that ensure the formation in the personality of professional orientation, general scientific competence, practical experience and professional readiness, which in turn is defined as a subjective state of a person who considers to be capable and prepared for the performance of certain professional activities and seeks to maintain it (Dubovytska, 2004). The end result of training is a willingness to innovate. Thus, I. Dychkivska characterizes professional readiness as a natural result of special training and self-determination, training and selfdetermination, education and self-improvement. It is important that the author emphasizes the importance of the formation of the mental active and an effective state of the individual, the nature of his/her quality, the system of integrated properties. One of the teacher's important qualities, according to the author, is his/her readiness to the innovation (Gromkova, 2012)

We share N. Batechko's opinion (Batechko, 2013) that the development of a master's program in Ukraine can be considered as a catalyst for innovative development of production and high technologies. We emphasize that master's training is more individualized and in-depth compared to a bachelor's degree. First of all, it provides the conditions for the creative development of a talented personality of a future specialist.

Master's studies are a special, self-sufficient period in the professional development of a future teacher. Students enrolled in magistrates are referred to as higher education graduates and sometimes 
simply undergraduates. Modern scholars characterize the students of the magistracy as professionally trained specialists, competent in the relevant field of education, who already have a bachelor's degree and are motivated for further education, self-education and educational activity through life (Aristova, 2008; Artemova, 2015; Gromkova, 2012; Kremen, 2005; Verbytskyi, 2003 and others).

We consider the preparation of the future teacher in the magistracy, on the one hand, as a reproduction of cultural and historical experience, and on the other it is as a mechanism for shaping the modern specialist's readiness for creative pedagogical activity in the context of a globalized educational space. At the same time, studies in the magistracy are described by scientists as the education of adults with the involvement of an andragogical model and taking into account the social and psychological features of an adult and a professional (Vitvytska, 2003).

In preparation for teaching and management, undergraduates study various pedagogical disciplines in theoretical, methodical and practical aspects. Master's studies change the motivation of future professionals. Thus, the focus on the habitual status of the future educator changes to the status of future teacher, organizer-manager of the education system. They not only consciously accumulate professional knowledge, but also formed beliefs according to each studied problem: knowledge of effective technologies, forms of pedagogical activity organization, both professional and creative; skills in working with scientific and scientific and methodical literature; readiness and ability to develop perspective curricula, programs, educational and methodical complexes, texts of various kinds lectures, system of seminars, practical, laboratory classes, ability to organize independent activity of students-bachelors and much more.

Higher education students acquire the skills of introspection and self-correction, the ability to implement innovative technologies in the organization of the educational process, and a readiness for activities is formed in them that in the future will enable them to organize the activities of those whom they will teach. In addition, future teachers acquire the skills to do their own scientific work and to manage the scientific work of students (future tutors). In particular, undergraduates master the methods of writing abstracts, research projects, preparation of reports, presentations, scientific articles, qualifications and experience (Shcherbakova, Shcherbakova, 2018). 


\section{Experimental and experienced part of work with recommendations}

Introducing into the pedagogical process of the Department of Preschool Education of Mariupol State University the normative course «Teaching Methods of Preschool Education» provides an opportunity to form an idea of the teacher's professional activity at the magistracy, to teach to characterize it as a professional and creative, to obtain knowledge about andragogy education and training andragogical model, to form the ability to analyze methodological and organizational and methodical aspects of the given issue (Shcherbakova, 2017).

Considering the fact that the students of the magistracy have already higher education and some experience of pedagogical activity, we aimed to organize their education with the andragogical model involvement (Artemova, 2015). It should be noted that the organization of bachelors training is based on the traditional pedagogical model of the future tutor preparation. This specialist training model has been usual, proven for decades. In such an organization of educational process the leading role is played by the teacher. He/she plans the educational process, stimulates students to acquire new knowledge and mastering general and special professional skills, controls and evaluates the quality of student achievement (Vitvytska, 2003). Unfortunately, on the basis of this model, the pedagogical process in higher education institutions is often organized not only during the bachelor's degree but also the master's.

As the experience of working with the students of the magistracy shows, in their professional training the attention should be emphasized on the active participation in this process by the higher education applicants themselves, their readiness to cooperate with the teacher and fellow students. Consequently, students in two higher education degrees work in parallel at higher education institutions: future bachelors and masters. But since undergraduates have already received higher education, it is natural that there should be a different andragogical model of education in which they are active participants not only in the discussion of problems but also in the planning and creation of the content of the educational process.

In comparison with the pedagogical model, the most important characteristics of the andragogical model are found in the active organization of independent activity of the undergraduate students, with the emphasis, first of all, on the problematical character and interactivity. Future teachers are systematically involved in the development and organization of didactic tasks of varying complexity, formulate the goals and objectives of individual information-didactic units (modules), project the results of the 
undergraduate students' learning activities, learn to analyze and to structure the scientific information, compare theory and practice, and etc.

The readiness of the future educator to teach the methodology of preschool education is considered by us as an integrated characteristic of the individual, which reflects a sufficient level of development of his/her professional potential; as a generalized and ultimate result of its purposeful preparation and includes the following components: value and content, emotional and volitional, methodological and cognitive, etc.

Adult learning and education is a key component of a holistic and inclusive life-style education system, which includes formal, non-formal and informal learning, which directly or indirectly refers to both young people and older people. In connection with this, recently the term «andragogy» is much more actively used. In Greek, it means «pedagogy of adult learning and education.» The goals of the future teacher preparation for professional activity in educational institution are realized on the basis of an andragogical model.

The content and structure of the future teacher's preparation of preschool education methods based on the andragogical model are presented in Fig. 1.

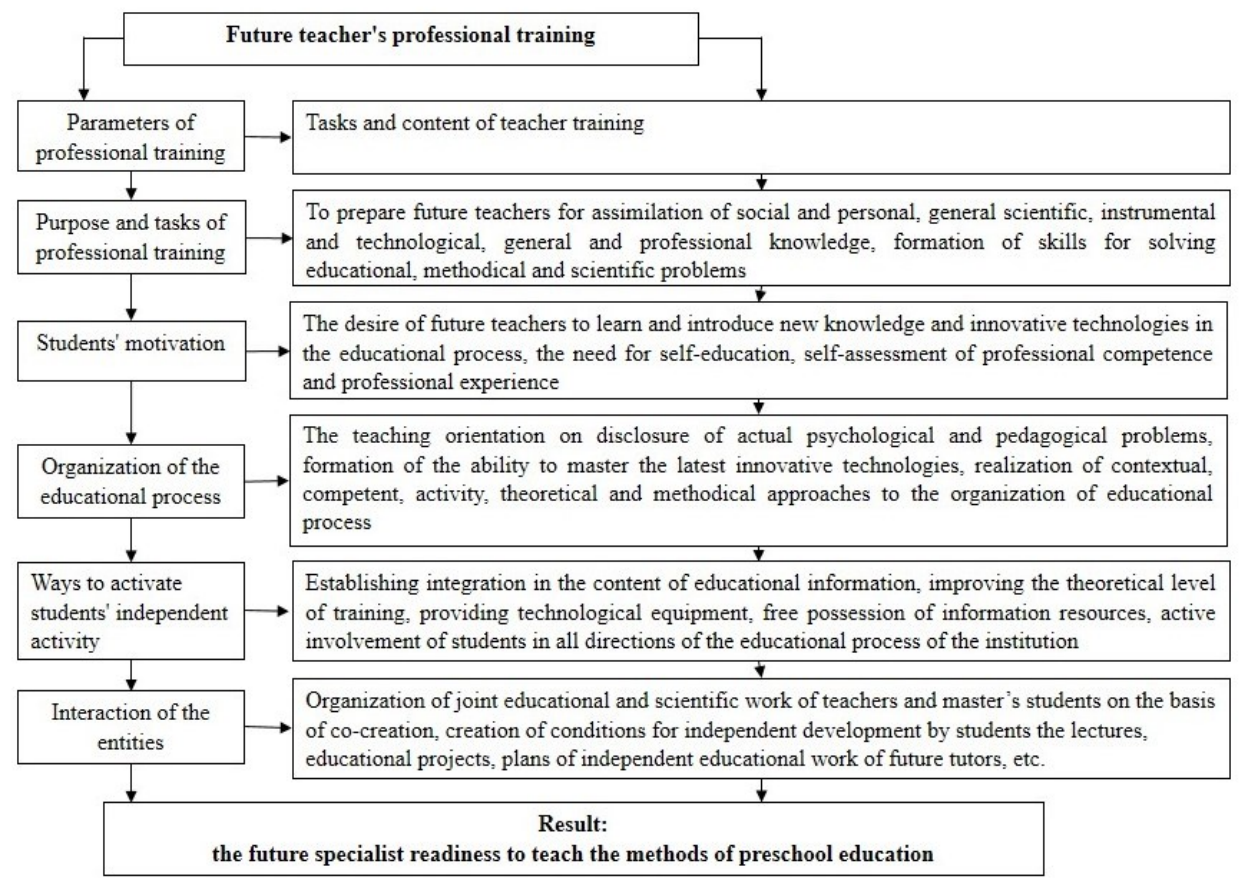

Fig. 1. Structural and functional model of the future teacher preparation to the preschool education methods 
The active participation of students in the work on this model allows future teachers to consciously build a self-education trajectory and motivates them to gain knowledge independently, using Internet resources, independent research and experimental activities.

Important indicators of future teachers' readiness for professional activity are their ability to creatively solve current educational problems, positive attitude to this process, readiness to build the educational process on the principles of integration, differentiation, individualization and democratization. The future teacher initiates his/her activity that contributes to the scientific, theoretical, technological basis of the training, improves the skills. His/her readiness means that he/she knows modern methodological approaches to the organization of educational process in higher education, understands the process of higher pedagogical education development and preparation of the future teacher as an active subject of professional activity organization in the system of pre-school education, has certain own professional achievements.

In organizing the process of teacher training in higher education institutions, we shared the views by L. Artemova, who, based on the research of M. Knowles, K. Kapp and others, demonstrates the experience of organizing the educational process in the course «Higher Education Pedagogy», based on the andragogical model of teaching undergraduates (Artemova, 2015).

However, in our experience in the planning and organization of the teaching activities of the master's students to their study of the course «Teaching Methods of Preschool Education», the focus was more on their readiness for the independent activity. In this regard, in organizing their educational activities, we primarily focused on the problematic and integrated content of training, as the most important characteristics of the andragogical model. Undergraduate students were systematically involved in the development and implementation of didactic tasks of varying complexity (reproductive, reconstructive and creative), independently formulated the goals and objectives of individual information and didactic units (blocks), developed programs, models of individual credits, content modules of specific educational disciplines. As a rule, seminars and practical classes included tasks of research, search character (educational and scientific projects of different types: informative and cognitive, organizational and active and creative). Thus, undergraduates were offered the following problematic tasks to discuss: «Do the state and personal values of education always coincide? How do you see the meaning of the personal value of education?» or «Explain the category of «educational outcome» in the logical order: literacy $\rightarrow$ education $\rightarrow$ professional competence $\rightarrow$ culture $\rightarrow$ mentality. What is the essence of 
continuity between these components of education?» In practical and seminar classes, the highest score was given not by students who found and copied the wise conclusions of modern scholars, but by those future teachers who formulated their own opinions on the problem and were ready to defend them, based on generally accepted theoretical provisions or comparing them.

We considered the preparation of the future teacher as a longitudinal process of improving his/her professional readiness. Generalization of the received data, which characterized the individual features of the master's professional training for teaching, made it possible to determine their readiness levels. In this regard, three levels of teacher professional readiness were conditionally distinguished: beginner - reproductive, basic - reconstructive, and bigh - creative. The content of each level can be characterized by distinguishing two components: competent and practical and behavioral. Fig. 2 presents the characteristics of future teacher's readiness for professional activity.

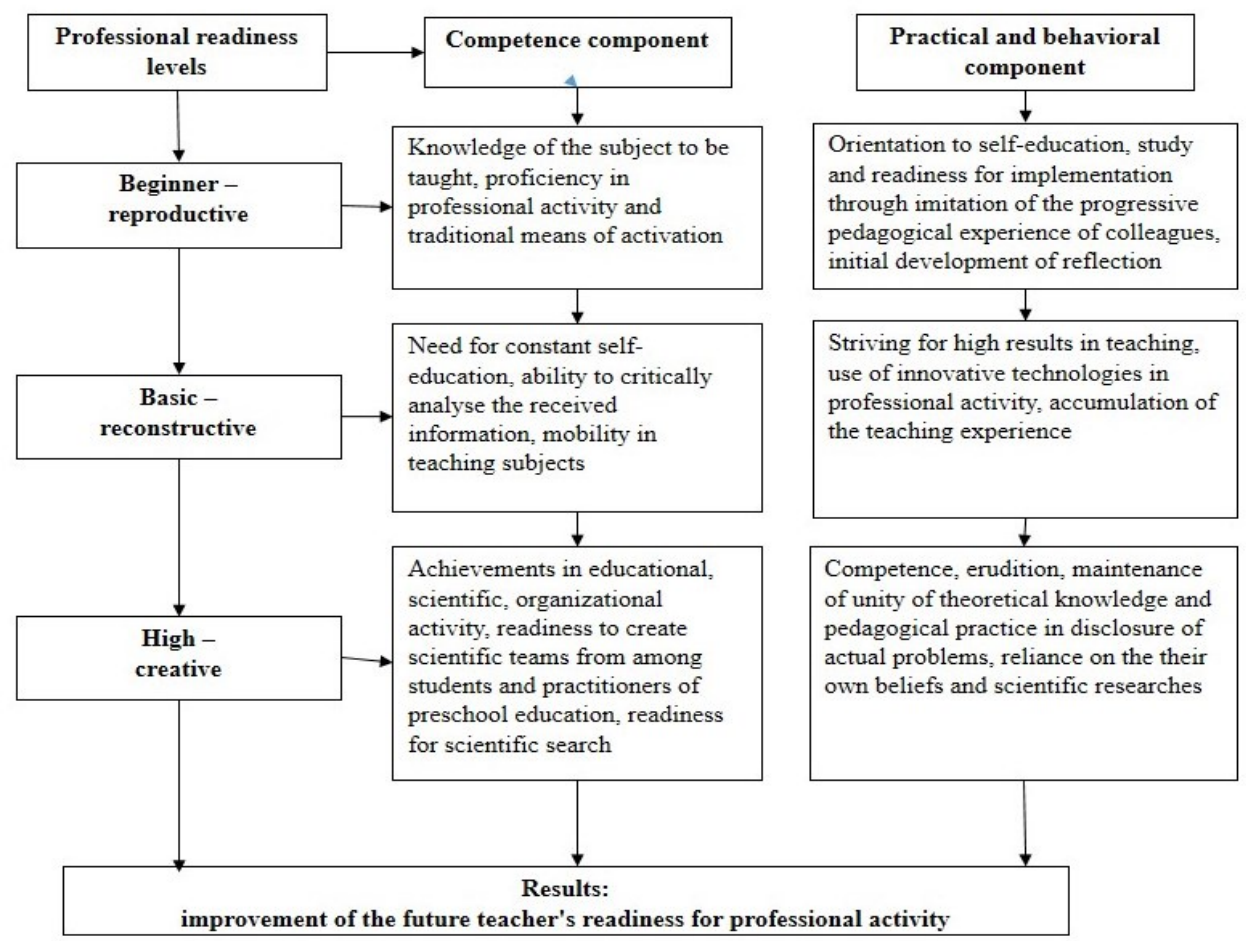

Fig. 2. Characterization of the levels of the future teacher professional readiness of preschool education methods 
Thus, characterizing the future teacher professional readiness, we relied on the following indicators: interest, independence, and self-criticism, desire for self-education and self-improvement, erudition, competence, selfrealization, creativity.

Based on this, you can define the content of each level. Thus, for the elementary - reproductive level, the character is as follows: the future teacher possesses the content of the discipline, has appropriate knowledge of teaching methodology, and seeks to adapt the message to the characteristics of the audience, their learning. He/she defines the purpose and structure of the class adequately the of the students readiness that he/she works with, shows the independence and self-criticism, focus on self-education and selfimprovement. But the student is not confident enough about his/her readiness for teacher qualification, is not ready to justify the system of application of active and interactive teaching methods. The higher education applicant has a reserve of professional knowledge, uses the statements of renowned scholars, tries to study and seeks to replicate the experience of his/her teachers i.e. the pedagogical education masters.

Future teachers of basic - reconstructive level of readiness for professional activity have a teaching strategy, have appropriate erudition and professional competences. They can model the mastering level of the students they teach. They aspire to use problematic teaching methods (search, investigative), which corresponds to the specifics of teaching in higher education institutions. But in their practical activity quite often the traditional methods and methods of a discipline teaching prevail. Activation of students in the classroom is carried out without deep didactic justification and self-assessment. The future teacher does not always seek to improve his/her own practical experience as an integrated characteristic of teaching activities (educational, scientific, methodical and organizational).

High - creative level of future teacher's readiness for pedagogical activity is characterized by the fact that the specialist directs the teaching of his subject to the formation of the personality of the future specialist. Forms and methods of educational activity he/she subordinates to the goal of the creative level realization of mastering students' knowledge, which can be characterized as the belief. They are good at the innovative pedagogical technologies. Important criteria for evaluating the effectiveness of educational activities are reflection and self-critical analysis. Projects activities of the students he/she works with according to specific pedagogical situations. The educator can organize educational dialogue, discussions, relies on scientific (preferably own) research. In pedagogical activity seeks to achieve high results. 
Introducing future masters to this characteristic of their levels readiness for professional activity, we suggested them to make a selfassessment of their own teaching readiness. By identifying themselves with one of the readiness levels, undergraduates attempted to argue their choices. Most of the future masters considered themselves basic - a reconstructive level of readiness for teaching (55-65\%). About 10-15\% of respondents said that they were already ready for teaching activities, identifying themselves at a high - creative level. While $20-25 \%$ of the respondents were more selfcritical and perhaps unsure and did not see themselves in the teaching profession. They considered themselves ready only to work with preschool children.

In order to substantiate their choice, future teachers had to first determine the criteria by which they had to prove the objectivity of the choice. And that was hard for them to do.

There were some differences of full-time and part-time students in the assessment of themself as teachers. A large number of full-time undergraduates believed that «principally they are ready to teach methods». Basically, they were excellent students.

The monitoring of the future teacher readiness, conducted by us at the end of the second and third semesters, made it possible to obtain more objective data and to prove the effectiveness of the organizational and pedagogical conditions for teacher training of the preschool education teacher created by us.

Therefore, we characterize the results obtained at the beginning of the study (beginning of the second semester). Unfortunately, there were no future high-level creative specialists. $40-45 \%$ of respondents were referred to the basic - reconstructive level. The rest (55-60\%) of the number of master's students had indicators of initial - reproductive level of teaching readiness. That is, they had theoretical and methodological knowledge that, unfortunately, could not be characterized as their own beliefs. However, they did not show confidence in their readiness for activity. As a rule, these students were eager to independence, but in practice mostly used readymade plans, abstracts, in practical teaching activities repeated (copied) the masters' experience in pedagogical education.

In order to increase the level of readiness of future specialists for teaching activities, we have identified and implemented in the educational process the following organizational and pedagogical conditions for training the educators:

1) organization of the educational process by the andragogical model on the basis of contextual, competence, activity and theoretical and methodological approaches; 
2) activation of future teachers' independent work through the use of different theories and innovative technologies;

3) fulfillment of educational and professional program in the work of future teachers of pedagogical disciplines unity of such its components: educational, scientific, methodical and organizational.

The organization of professional training of the undergraduates on the androgogical model allowed future teachers to build their own selfeducation program and motivated them to gain knowledge independently, using internet resources, independent, educational and experimental activities.

Important indicators of future teachers' readiness for professional activity are their ability to creatively solve current educational problems, positive attitude to this process, willingness to build educational process on the principles of integration, differentiation, individualization and democratization. The future teacher himself/herself initiates his/her activity; this is facilitated by the scientific, theoretical, technological basis of the preparation. He/she creates his/her skills. Their readiness means that they know the modern methodological approaches in the organization of the educational process in higher education, understands the process of education development and preparation of the future teacher as an active subject of the pedagogical process has certain professional achievements.

We attached particular importance to the methodology of teaching higher education students to ask questions of different levels of complexity and different cognitive orientation: reproductive, developing. Developing questions reveal the essence of the issue, summarize it, and contain research principles.

In order to future teachers be ready to teach pre-school teaching methods after graduation, they systematically perform relevant teaching, research, practical and research tasks from all the methods they have learned during their previous studies (at the bachelor's level). At the same time we understood that the future teacher should know the content and features of each technique. But we thought it was easier to know how to learn how to practice the principles and methods of teaching on the one methodology that each undergraduate chose at the beginning of the course. As an example there are such subjects as: «Theory and Methods of Logical and Mathematical Development of Preschool Children» or «Methods of Native Language Development,» «Fundamentals of Fine Arts with Methods for Guiding Children's Imaginative Activity», etc.

The tasks were different, for example, to draw up a program for conducting a problematic seminar for pre-school education institutions teachers; to develop test tasks for quality control of professionally oriented 
knowledge of the future tutor, etc. Undergraduates created educational and search projects of various types with appropriate methodology under the guidance of the teacher; developed individual modules of work programs according to a specific methodology of their choice; made supporting summaries of the lectures, based on modern information; made lists of basic and additional literature, prepared information and methodological support for the organization of independent work and recommendations for the fulfillment of individual tasks of undergraduate students; developed the abstracts for integrated and complex classes for preschool children, etc.

So, for the future teacher (specialty 012 Preschool education) in teaching the course «Fundamentals of Fine Arts With a Method of Directing the Pictorial Activity of Children» the content of these tasks can be as follows: to develop a lecture on the topic «Mastering a variety of technologies to engage preschoolers» or «Fine arts educator in aesthetic education of preschool children"; to compile a list of basic and additional literature for training a problematic seminar on the topic «Basic, copyright and additional programs in the visual, musical, theatrical and literary arts"; to develop test tasks for quality control of professionally oriented knowledge of the future tutor; to make an annotated list of literature on educational topics separately «Methods of teaching preschoolers to the drawing; applications; construction and embossment"; to help the educator to develop a lecture notes of the integrated application class on the theme «Ukrainian national clothing - a festive costume», taking into account different technologies in the method of its conduct; jointly with the tutor to develop the structure and content of the oriented notes for classes in circles with gifted children, who have expressed creative ability to draw, apply, design, sculpt, decorate; to develop a thesaurus dictionary to help the future tutor to study the course «Fundamentals of Fine Arts with Methods for Guiding the Children's Imagery « and etc.

Similar tasks were carried out by the candidates of master's education according to teh pedagogical disciplines of specialties: 012 Preschool education and 013 Primary education.

As evidenced by their own experience in the magistracy, an understanding of the essence of psychological and pedagogical concepts, an awareness of action ways, as well as the development of professional abilities contributes the various forms of independent work in different methods of pedagogical disciplines. The future teacher after active participation in the educational process of studying the discipline «Teaching Methods of Preschool Education» and after the professional-pedagogical (assistant) practice clearly understood the principles of constructing the content of the teacher's preparation such as: humanistic orientation, scientific, systematic, 
Trends and Prospects of the Education System and Educators' Professional ...

consistent development, communication of theory and practice, multifunctionality, dynamic of the program variable part, unification and differentiation, informativity, training adaptability, etc.

The particular importance in the preparation of the pedagogical disciplines tutor is the constant saturation of the educational process with the professional activity elements, such an approach in pedagogy of higher education is called the contextual approach (Verbytskyi, 2009). The contextual learning is the creation of a situation where the future specialist not only reproduces in practice the accumulated theoretical knowledge, but is gradually immersed in unpredictable pedagogical situations. In such situations, the higher education applicant seeks to actively solve practical problems in the professional activity. A special function in this regard is performed by laboratory classes and development of research projects of various types. Preparation of any type projects is a purely independent work, it is a logical link between teaching and pedagogical practice, it is a reflexive way when a future educator independently creates and practically analyzes a short, specific fragment of the pedagogical process. This is the living connection between theory and practice.

The concept of contextual learning can be implemented in two ways. The first is from mastering theoretical knowledge to putting it into pedagogical practice; the second is from practical testing or observation and evaluation of practical actions from the modern theories points. Both the first and second approaches can lead to the accumulation of one's own experience. In this approach, different theories of learning are used to solve pedagogical problems. One is the theory of problem solving.

According to the personal approach, it was important to use ascertaining data: the level of psychological and pedagogical knowledge of students, their willingness to choose the forms and means of mastering educational material. It provided the creation of a comfortable, conflict-free environment for the personal growth of the future teacher, education of such individual qualities as humanity, tolerance, respect for the others opinion, sociability, courage in expressing his/her own opinion, readiness to discuss, to defend the beliefs.

The resolution of problematic situations forces the future specialist to make connections between the individual structural components of the studied phenomenon. For this purpose, it is important for the student to be able to abstract themself from the concrete, to carry out a decomposition analysis of pedagogical phenomena and to learn to differentiate the connections between the elements in theory and to draw on these very connections (Verbytskyi, Dubovytska, 2004 etc.). 
The activity approach formed the basis of the future teacher's professional training; it ensured their active involvement and the educational process at lectures, seminars and individual classes in the system «teacherstudent», «student-student», and «student - academic group». In such a dialogue, future teachers designed, presented and argued how theoretical teaching material can be put into practice. The teacher was an active participant in the dialogue and helped students to solve problematic issues.

One of the didactic and methodological foundations of vocational training is project technology, which we considered as a system of educational and cognitive tasks and ways of interaction of the educational activity subjects, which allows to solve a specific problem by independent individual or collective theoretical and empirical actions of the educational recipients with a compulsory presentation of the work results.

In high school pedagogy, project technology is often defined as a model of person-centered learning. This is due to the fact that project technology as a certain system, which involves the interaction of taught that is the tutor and studied that is students - the applicants for higher education of the second level. In this case, the future specialist perceives himself/herself as an equal subject of such interaction. Project technology involves a set of interrelated tasks performed by students whose activities have some significant characteristics. Their actions are focused not only on assimilation and integration of actual knowledge, professional skills, but also on their independent acquisition. As a result, a corresponding personal pedagogical experience is formed.

To qualitatively prepare the future teacher for teaching pedagogical disciplines, it was necessary to provide them with information about the content, purpose, tasks, forms and methods of such a process. For this purpose, in the content of the training course «Teaching Methods of Preschool Education», a content module «Use of Educational Dialogue in Organizing the Educational Process with Students» was given. The main tasks of this module were: to form an idea of the essence of educational dialogue as a unity of educational, pedagogic, development and selfeducational functions on the basis of the scientific researches and pedagogical practice analysis; teach them how to analyze facts and phenomena, participate actively in discussions; to develop projects of different types, where each speech situation is a functional unit of oral speech, requires their direct and active participation and interaction with the teacher and classmates, and in further communication with the undergraduate students.

While developing the content of this module, we relied on the following characteristics as: adequacy of the purpose and specific task of 
general pedagogical preparation of the future teacher; a purposeful orientation on the formation of readiness for the organization of dialogue education in the future pedagogical activity in the students of higher education; context i.e. providing a link between the study of a theoretical course and the professional activities of a future teacher. The content of the module included the following topics:

Theme 1. Educational dialogue and its use in the modern educational process.

Theme 2. The purpose, content and structure of general pedagogical preparation of future educators for the organization of educational dialogue with children.

Theme 3. Communicative orientation of projects in the course «Teaching Methods of Preschool Education».

Purposeful work with students was carried out in stages. On the lectures, seminars, this information logically included in the structure and content of the training course, which allowed students not only to learn the educational dialogue theory, but also to realize the need to master the skills to organize it to ensure effective professional activity in higher education institutions.

The theoretical preparation of higher education applicants was to acquaint them in detail with the nature, functions, and types of educational dialogue, structuring the necessary interactions between the subjects of dialogue. We explained to future teachers the importance of properly formulated questions for conversation, discussion, debate; how to identify and resolve potential dialog interaction difficulties. Gradually their actions changed from reproductive to research. Therefore, the main element in working with projects was communication and problem discussion.

An important element in the future teacher professional development is his/her active participation in scientific and scientificmethodical activity. During the course of magistracy, future teachers need to develop a need for research activities, a willingness to independently create new educational and research projects that will be implemented in the original scientific searches of future specialists. At this stage, they should develop general scientific and research skills, namely: to perform a literary search, to compile a bibliography and to carry out a theoretical analysis of primary sources; substantiate the urgency of the problem, identify the contradictions between the data of science and pedagogical practice; clearly define the scientific apparatus of the research; apply scientific methods of cognition; substantiate the theoretical novelty and practical relevance of the study; logically build and conduct research; to have scientific language, to draw up the results of the study in figures and tables; prepare a presentation 
or poster presentation layout; to defend the results of the research in an appropriate form, to organize their own cognitive activities.

The master's educational professional program includes two approximately the same components in scope: 1) educational and 2) research. At the final stage of study in the magistracy the students pass three types of practice: organizational and methodical, professional and pedagogical (assistant) and research (writing, project and defense of the qualification work).

In the course of studying at the magistracy, higher education students acquire knowledge about science, its relation to education and the society development; about the essence of scientific activity; the content and types of scientific and pedagogical research, intellectual property, basic requirements for the organization and conduct of scientific research. Gradually, students acquire professional skills of the future practicing teachers, the pedagogical disciplines teacher, who is ready to organize their own professional activities, including their own research. The result of this activity is the protection of qualification work. The main task of its author is to demonstrate the level of their professional qualifications, the ability to independently conduct a scientific search and solve specific research tasks, to analyze the obtained experimental data, to argue the results dynamics. Qualifying work is the intellectual property of its author.

The future teacher, by his/her own example, is convinced that to write a qualification, he/she needs to have a broad erudition, a fundamental knowledge base, to have a scientific research methodology, modern information technologies, acquisition methods, processing, storage and use of scientific information.

One of the professional training areas of the future educator is his/her readiness to control and evaluate the results of teaching undergraduate students. Indicators of this area are their ability to perform tests, questionnaires, analyze the results of exam sessions, compare the results with the data of previous years, identify positive (negative) trends in learning and identify their reasons, analyze the student competitions results in the field of preparation, etc.

Monitoring data at the end of the third semester showed significant positive changes in the levels of future teachers' readiness for their professional activity. These changes are reflected in Table 1. 
Trends and Prospects of the Education System and Educators' Professional ...

Tab. 1. Dynamics of future teachers' readiness for professional activity

\begin{tabular}{|c|c|c|c|}
\hline \multirow{2}{*}{$\begin{array}{c}\text { Monitoring } \\
\text { stages }\end{array}$} & \multicolumn{3}{|c|}{ Readiness levels } \\
\cline { 2 - 4 } & $\begin{array}{c}\text { Initial }- \\
\text { reproductive }\end{array}$ & $\begin{array}{c}\text { Basic }- \\
\text { reconstructive }\end{array}$ & $\begin{array}{c}\text { High - } \\
\text { creative }\end{array}$ \\
\hline $\begin{array}{c}\text { The beginning of the second } \\
\text { semester }\end{array}$ & $55-60 \%$ & $40-45 \%$ & - \\
\hline The end of the third semester & $10-15 \%$ & $60-65 \%$ & $25-30 \%$ \\
\hline
\end{tabular}

The data obtained indicate that the graduates of the magistracy in the process of such training were aware of the need to create and implement appropriate organizational and pedagogical conditions that ensure the purposefulness, representativeness, objectivity and systematic control. Due to their experience, they have mastered the rating system in self-assessment of professional competences, which characterize their readiness, motivate to constantly improve their own achievements, increase initiative, responsibility, and creativity in independent professional activity.

Therefore, such a system of professional training of the future specialist allows the teacher of higher education institution to carry out individualization and apply differentiation of training.

\section{Conclusions. Prospects for further investigation}

The scientific and pedagogical experience of the authors on the problem of professional training of pedagogical disciplines teachers has allowed to systematize scientific data in this field of education and to present some of their own approaches and suggestions for solving our problem.

The experience of purposeful work shows that the andragogical model directs the activity of future teachers to the realization of educational goals of master's preparation for the professional activity; provides his/her natural cognitive need for self-education, readiness for educational, scientific, methodical and organizational activity.

Creating appropriate organizational and pedagogical conditions for the future teachers' professional training allows to take into account the level of each higher education student readiness to work independently, helps to develop in them reflection, self-criticism, an opportunity to organize themselves in educational and scientific teams, to take responsibilities, to bring the started to the end and to reasonably prove their position. 
The results of this work prove the prospect of further scientific research on the introduction of other innovative technologies in the preparation process of the pedagogical disciplines future teacher and improvement of the appropriate organizational and pedagogical conditions for effective assurance of his/her readiness for professional activity.

\section{References}

Aristova, L. (2008). Pedagogy and methods of higher education. Kiev: Condor.

Artemova, L. V. (2015). Features of adult learning. Preschool education in Ukraine: leadership in the profession. Kiev: Kyiv Ped. University after B. Grinchenko.

Batechko, N.G. (2013). Institute of Magistracy in Ukraine: Legal Principles of Functioning. Scientific works. Pedagogy. 215 (203), 128-133.

Belenka, G. (2018). Integrated Courses in Higher Education: Benefits and Risks. Education Innovation: Coll. of sient. papers, 7 (1). Rivne: RDGU.

Verbytskyi, A. A. (2009). Contextual learning: theory and technology. New Methods and Teaching Aids, (2), 51-54.

Vitvytska, S. S. (2003). Fundamentals of Higher Education Pedagogy. Zhytomyr: Zhytomyr Pedagogical University.

Goncharenko, S. U. (1997). Ukrainian Pedagogical Dictionary. Kiev: Lybid.

Gromkova, M. G. (2012). Androgogy: theory and practice of adult education. Moscow: UNITI-DANA.

Dychkivska, I.M. (2015). Innovative pedagogical technologies. Kiev: Academvydav.

Dubovytska T.D. (2004). Contextual learning: theory and practice. Intercollegiate Collection of Scientific Papers. A. A. Verbytskyi (Ed. T. D. Dubovytska). Moscow: Alpha.

Zharovtseva, T. G. (2006). Theoretical and methodological principles of the specialists' preparation of preschool education for work with disadvantaged families. Odessa: NCSTS of Ukraine - SVDMP Cherkassov.

The Law of Ukraine «On Higher Education». http://zakon2.rada.gov.ua/laws/show/1556-18.

Kremen, V. (2005). Education and Science in Ukraine - Innovative Aspects: Strategy and Implementation. Result. Kiev: Gramota.

Oliynyk, M. I. (2015). Training of pre-school education future specialists in the countries of Eastern Europe. Chernivtsi: Publishing House «RODOVID».

About the Concept of the organization of master's preparation in Ukraine: Order of the Ministry of Education and Science of 10.02.10. http://osvita.ua/legislation/Vichya osvita/7094/.

Funtikova, O. O., Shcherbakova, K. Y. (2016). Teaching methods of preschool education. Melitopol: Publishing House of Melitopol City Printing House. 
Shcherbakova, E.I., Pozdeeva, T.V. (2016). Master's studies: modern aspects of training. Praleska, 11, 29-32.

Shcherbakova, K., Shcherbakova, N. (2017). Methodology and organization of scientific research. Melitopol: Publishing House of Melitopol City Printing House.

Shcherbakova, N. (2017). Future Teachers Training in the Field of Instructional Dialogue Organization. Science and Education, 12, 165-170.

Shcherbakova, K., Shcherbakova, N. (2018). Organization of independent work of master's students. Scientific notes of Berdyansk State Pedagogical University. Series: Pedagogical Sciences: Coll. Sciences. Pap. (Num. 1). (260-267). Berdyansk: BSPU.

Shcherbakova, K. (2018). Andragogical model of specialist training in magistracy. Proceedings of the Fourth «Ukraine-EU» International Conference: modern technologies, economics and law» April 24-28. Mariupol: MSU.

Shcherbakova, K., Shcherbakova, N. (2018). Organizational and pedagogical conditions of teacher's professional training of the preschool education methods. Training of preschool education personnel as a resource for sustainable development of society. O.N. Antsypirovich (Ed), Coll. scientific pap. / Bel. state. ped. univ. after M. Tanka. Minsk: BGPU. 